\title{
Refugees and Higher Education
}

\author{
Georgina Brewis (University College London)
}

and

Sjur Bergan (Council of Europe)

Just one per cent of refugees of student age are today in higher education (UNHCR, 2016a). However, in many of the major refugee crises of the past special assistance for higher education students formed a significant part of overall relief efforts, and many universities continue to welcome refugees today. Often it is the more highly educated sections of society that form the majority of refugees, at least in the initial phases of a crisis (IEC and WUS, 1986). The recent Syrian refugee crisis, in particular, prompted the establishment of a range of scholarship schemes as well as new initiatives to deal with the problem of students who cannot document their qualifications. This entry offers an historical overview of major international aid programmes for refugee scholars, before outlining current problems facing refugee students and discussing the huge unmet demand for higher education among refugees.

\section{Historical overview}

In 1920 an international organisation called European Student Relief (ESR) was founded to send relief to students and academics facing severe hardship across the ruined universities of central Europe. National committees of students and professors channelled relief through its headquarters in Geneva. Aid for Russian refugee students who had left the newly-formed Soviet Union to continue their studies elsewhere, notably in Czechoslovakia, Yugoslavia and France, was key. The Czech Government subsidised the education of around 5,000 Russians and Ukrainians (Konstlán and Štrbáňová, 2011: 240) while the French Government spent hundreds thousands of francs in grants and bursaries (Johnston, 1988: 85-6). Refugees were further supported by groups such as the Russian Student Christian Movement - affiliated to the YMCA - and the American Committee for the Education of Russian Youth in Exile.

In 1933 the newly-created High Commission for Refugees coming from Germany asked ESR - now renamed International Student Service (ISS) - to accept responsibility for student refugees (Brewis, 2014). Between 1933 and 1936 around 7,000 Jewish students were expelled by the Nazis from the German universities. Of students who managed to emigrate 90 percent (c. 2,500) sought help from ISS offices in Geneva, Paris, New York, Leiden and London. Later, aid was secured for student refugees from Austria and Czechoslovakia. Organisations including the Rockefeller Foundation and the Academic Assistance Council (now CARA) worked to save thousands of senior scholars, but as Albert Einstein noted, help for students 'who have not yet made their names in the world' was a more difficult but nonetheless still important task (Brewis, 2014, 116).

International support for refugee and displaced students continued during the Second World War. A World Student Relief programme initially focused on the needs of student refugees and on enabling over 6,000 British, French, German, Italian and Polish prisoners of war to take university examinations while in camps (WUS, 1990). Between 1952 and 1958 the Ford Foundation contributed over $\$ 213,000$ to assistance for students of many 
nationalities who were displaced in Germany, Austria, Belgium, France, Greece and Turkey (Ford Foundation, 1958). Following the termination of the British Mandate in Palestine ISS ran a limited scholarship programme and since 1955 UNWRA (United Nations Relief and Works Agency) has provided access to university education for Palestinian refugees.

The 1956 Hungarian revolution presented opportunities to help refugee scholars on an unprecedented scale (Brewis, 2014: 166). In 1956-7 around twenty percent of the postsecondary student population of Hungary left for the West, including 5,000 university students (Hidas, 1998). Hungarian refugees received a more positive response from receiving nations than had their counterparts in the 1930s. West Germany, for example, offered 1,200 state-funded scholarships while Austria, Denmark, Norway, Sweden and the Netherlands aided smaller numbers. The Ford Foundation donated \$1 million for scholarships to be taken up in Europe (Hidas, 1998). Several hundred relocated to Canada, including 200 students and 14 faculty of the Sopron School of Forestry who migrated en masse to the University of British Columbia.

During the Cold War there was a continuous trickle of academic refugees across the Iron Curtain to Western European or North American universities. For instance students formed around seven per cent of the 10,000s of refugees who left Czechoslovakia between 1948 and 1953 (Konstlán and Štrbáňová, 2011: 248). The global World Refugee Year campaign (1959-1960) drew public attention to the ongoing refugee problem, and gained particular support from university students (Gatrell, 2011; Brewis, 2014). From 1966 the provision of scholarships for higher education became a central plank of the United Nations High Commission for Refugees (UNHCR)'s education work (Dryden-Peterson, 2011: 13).

After the 1960s a growing proportion of refugee scholars came from what was then known as the 'third world'. It became more common to support students to remain in their region of origin, with migration further afield encouraged only in extreme cases. In the 1980s WUS International worked to support students caught up in political conflicts in El Salvador, Guatemala and Honduras to study in Mexico, Nicaragua and Costa Rica (WUS, 1990: 7). In 1973 the overthrow of the Allende Government in Chile led to a number of new aid programmes, such as the scheme run by WUS UK that saw $£ 11$ million of UK Government money help 900 Chilean students over a ten year period (WUS, 1986; Philips, 2011). WUS UK also developed schemes for Ethiopian, Eritrean and Ugandan Asian students (WUS, 1990), while postgraduates and junior lecturers escaping Apartheid South Africa were supported by the Society for the Protection of Science and Learning (now CARA).

After the end of the Vietnam War in 1975 thousands of students from Vietnam, Cambodia and Laos sought refuge mainly in the USA but also in Canada, Australia, France and elsewhere, as part of wider population movements from South-East Asia (Nguyen-HongNhiem and Halpern, 1989). One response to this new crisis was the establishment in 1978 by WUS Canada of a new Student Refugee Program, which had awarded 1,000 scholarships for study in Canada by 2008 (Peterson, 2010).

During the 1990s there was a shift away from traditional scholarship schemes, although these are still encouraged by the UNCHR's education strategy 2012-2016. The largest such programme remains the Albert Einstein German Academic Refugee Initiative Fund administered by UNHCR and funded by the German Government, which since 1992 has provided 6,000 scholarships. 


\section{Recognition of qualifications}

Since summer 2015 the number of people seeking refuge in Europe has increased dramatically. Some 1 million persons claiming refugee status arrived in Europe by sea in 2015 and more than 200,000 in the first five months of 2016 (UNHCR 2016b). There are currently some 4.8 million Syrian refugees and 6.5 million internally displaced Syrians, and approximately half of them are children (World Vision 2016). In spite of the scepticism with which refugees are sometimes met in Europe, many universities actively welcome refugee students. A Refugees Welcome Map maintained by the European University Association (EUA 2016) includes more than 200 institutions in 31 countries which have taken measures ranging from financial support through integration measures to facilitating access to higher education.

The Lisbon Recognition Convention (Council of Europe/UNESCO 1997) includes provisions on the recognition of qualifications held by refugees, internally displaced persons and persons in a refugee-like situation (Article VII). A survey of the implementation of the Convention (Council of Europe/UNESCO 2015) shows that 70 per cent of the 53 states party to it have not taken concrete measures to implement this Article, which was included in the Convention following the breakup of the former Yugoslavia. An important issue is that many refugees for good reasons cannot document their qualifications. They may have been unable to take documents with them, institutions may be unwilling to help former students who fled and contacting institutions may be difficult. Those who cannot document their qualifications today may be unable to do so in the future as archives may have been destroyed.

Interviews may establish whether refugees are likely to have the qualifications they claim but cannot document these. A project in Norway has established a qualifications passport for refugees on this basis and reports good results (NOKUT 2016). It estimates the cost per passport at 5000 NOK (approximately 550 Euros) and suggests the passport be valid for three years.

A qualifications passport is not a diploma or a formal recognition decision but will provide valuable information to employers and education institutions on the qualifications the refugee is considered to have demonstrated during the interview. A European format, as proposed by the Norwegian and United Kingdom recognition information centres (NOKUT 2016), would make it possible for refugees to obtain recognition in other European countries when they cross borders, e.g. under an EU resettlement scheme, and would make it unnecessary to reassess qualifications that have already been assessed in a previous host country. Accepting such qualifications passports will require modifying legal regulations in some countries and changing practice in many more.

This is, however, essential and the stakes are high. Access to higher education for refugees remains limited and is of low priority among donors today, despite the aspirations of refugee youth around the world (Dryden-Peterson and Giles, 2011). Yet education is key to providing the knowledge and skills refugees need to find a meaningful place in their host societies as well as to enabling them to play a role in reconstruction in their home countries if and when they are able to return. Refugees who are able to use their qualifications for further study can come through this difficult period motivated and with new competences. 
Refugee students or graduates who are condemned to passivity can become demotivated, may lose the qualifications they already have for lack of practice and there are fears a minority may even turn to violent extremism.

1586 words

\section{References}

Brewis, Georgina. 2014. A social history of student volunteering: Britain and beyond, 18801980. New York and London: Palgrave Macmillan.

Brewis, Georgina. 2015. Student solidarity across borders: Students, universities and refugee crises past and present. London: History \& Policy. http://www. historyandpolicy.org/policypapers/papers/student-solidarity-across-borders-students-universities-and-refugee-crises, accessed 10 May 2016.

Cohen, Susan. 2010. Crossing borders: Academic refugee women, education and the British Federation of University Women during the Nazi era. History of Education 39, no. 2: 175182.

Council of Europe/UNESCO. 1997. Convention on the Recognition of Qualifications concerning Higher Education in the European Region (Lisbon Recognition Convention). http://www.coe.int/en/web/conventions/full-list/-/conventions/treaty/165. Accessed 9 June 2016.

Council of Europe/UNESCO. 2015. Monitoring the Implementation of the Lisbon Recognition Convention. Preliminary draft report 18 December 2105. Unpublished.

Czigány, Magda. 2009. "Just like other students": Reception of the 1956 Hungarian refugee students in Britain. Newcastle: Cambridge Scholars.

Dryden-Peterson, Sarah. 2011. Refugee education: A global review. UNHCR. Available online http://www.unhcr.org/4fe317589.html, accessed 4 May 2016.

Dryden-Peterson, Sarah and Wenona Giles. 2011. Higher education for refugees. Refuge 27, no. 2: 3-9.

EUA. 2016. Refugees Welcome Map.

http://refugeeswelcomemap.eua.be/Editor/Visualizer/Index/34. Accessed 9 June 2016.

Ford Foundation. 1958. Final report on the Ford Foundation program for refugees primarily in Europe.

Gatrell, Peter. 2011. Free world? The campaign to save the world's refugees, 1956-1963.

Cambridge: CUP.

Hidas, Peter. 1998. The Hungarian refugee student movement of 1956-1957 and Canada.

Canadian Ethnic Studies 30, no. 1: 19-49.

International Extension College and World University Service, 1986. Refugee education: The case for international action. Cambridge. 
Johnston, Robert, H. 1988. "New Mecca, new Babylon": Paris and the Russian exiles, 19201945. Kingston and Montreal: McGill-Queen's University Press.

Konstlán, Antonín and Soňa Štrbáňová. 2011.Czech scholars in exile. In Marks, Shula, Weindling Paul, and Laura Wintour eds. In defence of learning: The plight, persecution and placement of academic refugees, 1933-1980s, 239-256. London: Oxford University Press for the British Academy.

Nguyen-Hong-Nhiem, Lucy, and Joel Martin Halpern, 1989. The Far East comes near: autobiographical accounts of Southeast Asian students in America. Amherst, University of Massachusetts Press.

NOKUT. 2016. NOKUT's Qualifications Passport for Refugees Pilot project February-May 2016.

http://www.nokut.no/Documents/NOKUT/Artikkelbibliotek/Kunnskapsbasen/Rapporter/UA /2016/Malgina_Marina_Skjerven_Stig_Arne_NOKUTs_Qualifications_Passport_for_Refugee s_1-2016.pdf. Accessed 9 June 2016.

Peterson, Glen. 2010. "Education changes the world": The World University Service of Canada's student refugee program. Refuge 27, no. 2: 111-121.

Philips, Alan, 2011. Refugee academics from Chile: WUS-SPSL collaboration. In In Defence of Learning, 281-290.

World University Service. 1986. A study in exile: A report on the WUS (UK) Chilean refugee scholarship programme. London: WUS.

World University Service, 1990. Education for development: Annual report 1990.

UNCHR. 2012. Education strategy 2012-2016. Geneva: UNCHR.

UNCHR. 2016a. Education. http://www.unhcr.org/pages/49c3646cda.html. Accessed 12 May 2016.

UNHCR. 2016b. Refugees/Migrants Emergency Response - Mediterranean.

http://data.unhcr.org/mediterranean/regional. php. Accessed 9 June 2016.

World Vision. 2016. Syria refugee crisis FAQ: How the war is affecting children.

http://www.worldvision.org/wv/news/Syria-war-refugee-crisis-FAQ. Accessed 9 June 2016. 